\title{
Openness to Disappointment: The Role of the Subject in Gadamer's Hermeneutics
}

\section{Abertura para o desapontamento: \\ o papel do sujeito na hermenêutica de Gadamer}

\author{
Prof. Dr. Michael Steinmann \\ msteinma@stevens.edu \\ Stevens Institute of Philosophy/NJ - USA
}

The paper concerns the role of the subject in Gadamer's hermeneutics. This role is notoriously difficult to define: due to his criticism of traditional metaphysics, Gadamer refers to the subject only in a negative way. It is not given any constitutive role with respect to language, art, or history. However, hermeneutic experience has to involve the subject in a more or less active way: without the subject, understanding and the dialogue with others could not happen at all. The paper traces the role of the subject in the phenomenon of openness, which requires receptivity toward the meaning of other persons or texts. Openness, however, cannot be captured as such. A more explicit form of subjectivity can be seen in negativity, which for Gadamer is a necessary aspect of experience. Finally, the paper refers to his interpretation of Plato's dialectic, which could have served as a model for the way the subject educates herself to become open.

KEY-WORDS subjectivity; negativity; openness

O artigo diz respeito ao papel desempenhado pelo sujeito na hermenêutica de Gadamer. Tal papel é notoriamente difícil de definir: devido a sua crítica à metafísica tradicional, Gadamer se refere ao sujeito apenas de modo negativo. Não é dado qualquer papel constitutivo em relação à linguagem, arte ou história. Contudo, a experiência hermenêutica precisa envolver o sujeito de maneira mais ou menos ativa: sem o sujeito, simplesmente não poderia ocorrer compreensão e diálogo com outros. $\mathrm{O}$ artigo traça o papel do sujeito por meio do fenômeno de abertura, que requer receptividade em direção ao sentido de outras pessoas ou textos. A abertura, contudo, não pode ser capturada como tal. Uma forma mais explícita da subjetividade pode ser vista na negatividade, que para Gadamer é um aspecto necessário da experiência. Finalmente, o artigo faz referência a sua interpretação da dialética de Platão, a qual poderia ter servido como um modelo para a forma de educarse do sujeito para tornar-se aberto.

PALAVRAS-CHAVE subjetividade; negatividade; abertura 
In Gadamer's Truth and Method, the subject appears like an optical illusion. At the first glance, it is everywhere. Its most obvious appearance can be found in the "Analysis of historically effected consciousness," which for many - amongst which Heidegger was certainly the most important - gave rise to the suspicion that Gadamer had fallen back into a traditional metaphysics of the subject as an agent of understanding and creator of meaning. Gadamer vehemently defended himself against this claim, stating that his use of the word consciousness "meant only an alignment (Anpassung) to a use of language which seemed natural to me" (1993b, 10). In reality, he added, playing on the tacit components of the German word, consciousness entailed for him "mehr Sein als Bewusstsein," more being than being conscious (11). This, however, means that it is indeed "natural" to read the whole account of hermeneutic understanding from the subjective point of view. At the end, who is undergoing the presumed experience of art, language, history, and truth, if not the individual subject? Despite the emphasis on being, it is the being of consciousness that seems to be at the center of Gadamer's analysis.

But then, at a second glance, the subject that seemed to be everywhere is gone, and all we find is being. This maneuver through which the ever-present subject is made to disappear into the structures of being is in fact the most important move in Gadamer's hermeneutics. For him, the subject is always already involved in the process of the unfolding of truth which is both substantive (sachlich) and dialogical. She has no constitutive force in determining the meaning of an object or a text, but rather finds herself embedded in the inherent meaning of language and the process of tradition, understood as effective history. Both unfold in a realm that exists as "a beyond of subjectivity" (Gadamer $1995,99)$. This way, hermeneutics provides a fundamental criticism of the role subjectivity played in modern philosophy.

Still, we have to ask whether the subject is really gone. Even Gadamer makes clear that the effective history through which tradition continues itself requires as its counter-part an individual's openness. The individual has to feel addressed by history, or even challenged, and she has to be willing to become involved in the unfolding of truth. In Truth and Method, the motive of openness functions as a guiding thread that links different chapters and analyses. It is repeatedly described as a specific sense and receptivity for the voice of tradition. Certainly, such receptivity excludes the affirmation of subjective faculties. Openness is never mastery. But on the other hand, it is not self-evident that individuals even possess the openness they need to have. How can they be sure to have the appropriate openness toward tradition in the whole depth of its meaning, if not through a certain personal commitment to understanding? 
Without an individual engaging actively in the dialogue with others, or with a text, this dialogue would not happen at all. In one way or the other, subjective openness needs to be experienced, which means that the subject has to experience herself as an integral part of the process of understanding. But not only this: openness needs also to be cultivated and learned. An individual cannot simply claim to be open toward the voice of others, because then true openness could not be distinguished from the mere pretension to be open. Openness is a specific way in which an individual conducts herself, and it can be achieved in various degrees and forms. This means, again, that it has to be experienced in a somewhat explicit way.

In the following, we will try to shed some light on the role of the subject in the process of understanding. A role or function that does not presuppose by any means an ontology of the subject as a separate, underlying thing but only an awareness of our personal involvement in the unfolding of meaning and truth. We are the ones - and no one else - who experience meaning, even if we are aware that there is more to it than we are able to constitute. Otherwise, who would be able to say that there is more? Gadamer makes this sufficiently clear:

Hence I must emphasize that my analyses of play and of language are intended in a purely phenomenological sense. Play is more than the consciousness of the player, and so it is more than a subjective act. Language is more than the consciousness of the speaker; so also it is more than a subjective act. This is what may be described as an experience of the subject and has nothing to do with 'mythology' or 'mystification.' (TM XXXIII)

The ontological significance of language, or of history, would remain a metaphysical construct without the corresponding experience in and through the subject. The being of hermeneutics Gadamer referred to is not the being of metaphysics but the correlate of a phenomenological analysis in which it has to reveal itself both descriptively and intuitively. For the sake of following a strict methodical approach, it is necessary that the subject of understanding feels herself involved in the being of historical meaning. Although it is possible to give a conceptual account of this experience, it first has to originate in such a purely phenomenological way. 
Our account will start from an analysis of the structure of openness. As an attitude of the subject, openness is paradoxical because in being open toward others or tradition the subject cannot experience herself as such (1.). For this reason we will look for other aspects in Gadamer's work that allow us to find such an experience. This will lead us to the phenomenon of negativity which, for Gadamer, is a general condition of experience and a necessary step in the process of understanding (2.). In the final chapter we will refer to his interpretation of the Platonic conception of dialectic. We will see that Gadamer, who always rejected the idea that openness could be consciously achieved or learned, could have used dialectic as a model for the education and cultivation of openness (3.).

This way, our investigation will lead us from a more formal analysis of subjectivity to a specific experience of it and finally to its cultivation. Such a trajectory does not come by chance: taken as such, the mere fact that the subject has to be part of the process of understanding does not carry much weight. Gadamer's remark according to which it is "natural" to use the idea of consciousness is right insofar as the idea can indeed be used without any strong philosophical implications. In hermeneutics, nothing much follows from it. For this reason we have to look for an experience in which the subject becomes aware of herself in a more specific, particular way, which is the experience of negativity. Eventually we have to look for a way in which the subject actively contributes to the process of understanding. Hermeneutics is based on the practice of understanding, which means that the subject also has to be located in a place where it has practical implications. Instead of a formal, or rather neutral, ontology of the subject, which would be meaningless at best, we are asking for the concrete and lived experience in which subjectivity emerges and relates actively to itself.

\section{The Paradox of Openness}

The theme of openness runs through the different parts of Truth and Method. It can be seen as one of the guiding threads that connect the various aspects and levels of this work. (GRONDIN, 2002, p. 44-45) Already the first of the classical humanistic notions that are introduced at the beginning of the book to emphasize how important this tradition continues to be for all studies in the humanities, the notion of "Bildung" (which in English translates only partly as "formation" or "cultivation"), is related to this thread. Bildung, according to Gadamer, means "keeping oneself open to what is other - to other, more universal points of view." (TM 15/22) It involves "tact," as a certain "sensitivity 
and sensitiveness" which for him is necessary in approaching "the aesthetic and historical." (TM 14/22) In order to possess true Bildung, one has to have respect for the richness and depth of the humanistic tradition. Later on, the theme recurs in the analysis of the productive use of prejudice. It is neither possible nor necessary to eradicate all our prejudices in interpretation, Gadamer claims, because "all that is asked is that we remain open to the meaning of the other person or text." (TM 271/273)

Openness achieves its most prominent role in the analysis of "historically effected consciousness." It characterizes, first, the very idea of hermeneutic experience. In it, openness means more than having a welcoming attitude toward others or a text:

I must allow tradition's claim to validity, not in the sense of simply acknowledging the past in its otherness, but in such a way that it has something to say to me. This too calls for a fundamental sort of openness. (TM 355/367)

In hermeneutic understanding we have to start from the assumption that a text or the other's words are relevant for us, and that they raise at least the question of truth, even if we do not accept the claims they make. But openness is also fundamental for the questioning that drives the interpretation of texts or other persons. Gadamer emphasizes

the priority of the question in all knowledge and discourse that really reveals something of an object. ... To ask a question means to bring into the open. The openness of what is in question consists in the fact that the answer is not settled. (TM 357/369)

The truth of another person's words or of a text can be revealed only if our understanding does not already delineate or determine the truth it wants to achieve but passes through a stage of genuine openness. The truth we want to understand in others cannot be the truth we have already understood.

1 See also TM 298/304. 
Openness, hence, is a fundamental structure both of hermeneutic experience, as a sort of exposure to the meaning of others, and the interpretative questioning in which we actively engage. In addition, as we have seen above, it is the sign of a truly cultivated (gebildet) spirit and so determines one's demeanor in the world. Finally, it entails a reflective attitude toward oneself, which limits the influence of one's ineradicable prejudices. This means that openness is a quality both of ethos and of logos; part of an individual's life-conduct and intuitive reactions to the world, and her way of critically examining herself and others. In all these aspects it can be seen as a phenomenon of subjective life; openness involves subjectivity in an intellectual, emotional, and practical way. Does this mean that openness allows us to see the role of the subject in understanding? At the end, the answer is no. Even if openness is the place at which the subject is most clearly present, whenever we try to grasp it as such it slips from our hands.

The reason for this slipping away of openness lies in its paradoxical nature. On the one hand, openness presupposes not only a general sense for the voice of tradition but a sense for the voice of tradition in its particular otherness. (TM 271/273) The receptivity of understanding is no immediate conflation with the meaning of others or a text; it is no act of empathy or a forgetfulness of oneself. Quite the opposite is true: the others or the text are first seen from a distance. What speaks to us is not already given in the horizon of our anticipations. This awareness of the otherness of tradition is a necessary step in the process of understanding: in order for us to become aware of our own prejudices, to make the vantage point of our own understanding clear, we have to be able to see the difference between our horizon and the meaning that unfolds through the speaking of the others or the text. As we have indicated before, the subject's vantage point, according to Gadamer, does not need to be neutral or void, the subject only has to develop a certain critical consciousness toward herself. (cf. TM 271/274) Hermeneutics is, at least in parts, nothing else than such a critical restriction of the readiness to understand. With $\mathrm{r}$ spect to tradition, it has its place in the "in-between" of "strangeness and familiarity" (TM 295/300), that is, in the very moment of transition where it still remains to be decided whether the tradition will be continued or not. The openness toward tradition, hence, is achieved not only by listening to the voice of others but, more important, by restraining one's impetus to fully understand what they say. It requires the acceptance of the "strangeness" of meaning.

On the other hand, the power of this critical stance is limited, and its relevance is only preliminary. Our prejudices are not at our complete disposition. We cannot fully grasp and illuminate our own vantage point, it simply escapes 
our mastery. (TM 295/301) This means that the critical self-control that is necessary to give justice to the voice of others cannot be achieved through our understanding alone. We rather have to rely on something beyond ourselves - on the very tradition we interpret and examine. If we face tradition honestly and openly enough, all our prejudices "die away," Gadamer states. (TM 298/304) It is as if tradition examined $u s$, and all our misunderstandings, all limitations that our particular point of view might entail, were washed away by an overwhelming experience of meaning. What remains are the good prejudices, the ones through which we are able to receive and accommodate the meaning of tradition. By letting our particular, inappropriate prejudices die away we become part of the effective history through which tradition continues itself. The critical examination is fulfilled once the otherness of the text or the other is allowed to speak; not as otherness separated from us but as an enrichment and productive transformation of our own voice.

Openness, hence, is paradoxical because it requires us to have both selfrestraint and transcendence toward the otherness of others or a text. It involves the highest, critical selfawareness of the subject and at the same time her fusion with the encompassing life of tradition. Subjects become aware of themselves only to "hold away" what might prevent the unfolding of truth. (TM 272/274) ${ }^{2}$ Eventually, as subjects they "disappear." This means that openness, truly achieved, cannot see itself as openness but only as commitment to the otherness of others and as seriousness of engagement. If we bring this into a formula we can say: those who are open cannot see that they are open, and those who think that they are open are in reality not. If openness remains an attitude of the subject alone, it is not true openness. True openness is transcendence and does not see itself as the subject's merit or possession. ${ }^{4}$

If we tried instead to hold on to a stronger, more explicit notion of subject, if we tried, so to speak, to prevent it from slipping away in its self-transcending move, we would not only miss a crucial point in Gadamer's hermeneutics. We would also miss its critical potential and indeed fall back into a more or less naïve form of metaphysics. In his famous definition of historical being Gadamer

2Translation modified.

3 See the last phrase of Gadamer's Text and Interpretation: "The interpreter gives his reasons, disappears, and the text speaks." (Gadamer 1989, 51)

4 Tact is described as a "tacit and unformulable" sense. (TM 15/22) The German words used here are Unausdrücklichkeit and Unausdrückbarkeit. It might be worth noting the different ways in which openness can be understood. For Gadamer, "openness has little to do with being open-minded, as compared to someone who is prejudiced (in the narrow sense of the term). The openness is the exposure to what confronts us to an other." (Risser 1997, 90) 
states that "historicity means to never fully equate to knowledge of oneself." $(\text { TM 301/307) })^{5}$ The knowledge that we actually achieve both of our own point of view and of the meaning of tradition relies on a deeper unity through which history has always already taken possession of us and continues to live precisely through our understanding. Such continuity of tradition is both the ground and the condition of possibility of every singular, subjective act of interpretation. By turning it against itself, Gadamer integrates the whole heritage of critical thinking into his hermeneutics: critique, in its most advanced and radical form, is the critique of the capacity to criticize oneself. It limits first and foremost itself and so helps the subject to commit to the underlying continuity of historical being.

However, even if we accept this turn of critique against itself, subjective openness remains a necessary and even sufficient condition of understanding. Necessary because we understand the others only if we are open for their voice, and sufficient because insofar as we are open, we cannot not understand (openness is understanding, not a pre-condition separated from it). The liveliness of tradition is nothing but our capacity to keep it alive and add our own perspective to the richness and depth of its meaning. There is no such thing as a tradition separated from us, because the moment it could be separated, it would die. Gadamer's conception was often misunderstood, as if he intended a purely objective, anonymous process of truth. He contributed himself to such misunderstandings, for example through his famous remark on subjectivity as a "flickering in the closed circuits of historical life." (TM 278/281) But such an objectivist notion of tradition ultimately cannot hold up: the tradition would come to an end without the interpretative questioning that only subjects are able to undertake. Our question, hence, remains unshaken: what is the subject's contribution to the unfolding of truth? How does she experience herself in the process of understanding? And how can she achieve or simply learn the openness that is necessary to appreciate a horizon different from and much vaster than her own? Again, it cannot be taken for granted that subjective openness exists. There are, however, aspects in Gadamer's work that allow for such a stronger and more explicit experience of the role the subject plays. We will describe them in the following chapters.

5 Translation modified. 


\section{The Negativity of Experience}

As we said before, the role of the subject is most directly described in the analysis of "historically effected consciousness." One of the key notions of this analysis is the notion of experience. We have used it in the previous chapters without giving it proper attention. For Gadamer, experience in its most elementary sense has to be understood as "an event over which no one has control, ... in which everything is co-ordinated in a way that is ultimately incomprehensible." (TM 347/358) According to the "original meaning" (TM 341/352) of the term, experience is more than an intake of sensory data. It means to be confronted with an open-ended process through which new and unexpected insights are revealed, and it means to be exposed to elements and structures of the world which eventually cannot be further explained. Compared to that, the notion of experience used in scientific research is much narrower; it has to "abolish" the unexpected and incomprehensible character of events in order to make them appear "in principle repeatable." (TM 342/353)

What is most decisive here is that, for Gadamer, experience in its original, prescientific sense "is essentially negative." (TM 347/359) It does not unfold as a linear and steady accumulation of knowledge, but involves ruptures and revisions that lead very often to no positive result at all. The knowledge we acquire through experience always bears the marks of this tedious process. Gadamer uses the word "insight" to distinguish simple instances of knowing from the type of knowledge that experience provides: "insight is something we come to." (TM 350/362) Together with what we know about something we also know the way in which such insight was achieved, how much it has cost us in terms of an effort we had to make. This also means that the achievement of an insight would not be relevant or even remarkable for us if it were not marked by the contrast to what we knew before:

Experience ... inevitably involves many disappointments of one's expectations and only thus is experience acquired. That experience refers chiefly to painful and disagreeable experience ... can be seen directly from its nature. (TM 350/362) 
At the first glance, Gadamer's conception might seem too narrowly linked to the model of personal experience. While our personal encounters with the world are indeed very often "painful and disagreeable" for us, the experiences we make in more neutral and methods-based settings, that is, in the settings we assume to be "scientific," seem to be free from any such pain. But for Gadamer, expectations are a necessary condition of every understanding, both pre-scientific and scientific, so that every understanding reaches insight only by becoming aware that an object is seen differently compared to how it was seen before. The question whether individuals actually feel pain in their experiences is not relevant for that, and can hardly be answered in any general way. What counts is that experience necessarily involves a play of expectation and disappointment and proceeds through the contrast of familiar and unexpected insights into the world.

This intrinsic negativity of experience finally allows us to delineate a phenomenon in which the role of the subject in understanding comes explicitly to the fore. In a certain sense, the whole chapter on "historically effected consciousness" deals with the role of the subject, and it is obviously not by chance that Hegel's phenomenology of subjective spirit becomes a crucial testimony for Gadamer in it. (cf. TM 348-350/359-361) If the process of experience were inherently positive, leading to new insights in a straight, teleological way - by adding one insight to the other, until a sufficient degree of completeness is reached - the subject would not need to be particularly aware of her own preconceptions (which is precisely the ideal of positive science where subjective attitudes are not supposed to matter at all). Only negativity makes the subject aware of herself by showing the limitations and short-comings in what she is able to understand. Insofar as the meaning of an object or a person cannot be fully accessed, at least temporarily, insofar as it withdraws from our attempt at capturing it, we become aware of ourselves: of us as the negative counter-part to a phenomenon in which meaning is impenetrably enclosed.

Obviously, this experience of the subject as the negative of the world is only a phase in the process of understanding. As we have seen, the gap between the subject and the other person or a text is bridged once the former becomes aware that the meaning of the latter, which initially seems unexpected and incomprehensible, is one that she already implicitly shares. The subject has no fixed, substantial position vis-à-vis the other person or a text but is eventually drawn into the meaning they reveal. She gives her own negativity up and absorbs the position of the other.

This raises the question whether the negativity of experience can be more than a transient phase. Could it not become a more permanent stance in which the subject relates to herself, in a way in which such stance would not come and 
go with each new act of understanding? Through negativity the subject could achieve the radical openness that is necessary for the transcendence toward the other. Being open to experience as disappointment could become a way of conducting one's life. Gadamer does not seem to be willing to draw such conclusions from his analysis. For him, it is impossible to suggest that understanding could in any sense come close to an art, to a conscious and methodical use of tools that can be mastered, that is, taught or learned. He straightforwardly rejects, for example, the idea that questioning could ever be seen as an art, because in order to raise questions deliberately one must already know what it means to be open to the meaning of others. ${ }^{6}$ Questioning starts from a way of being, not from an intentional act we can consciously perform whenever we see fit. But then, there seems to be no reason why this way of being should not be modifiable for us. The dichotomy of being and act, if it is understood to mean that we can have only one or the other, is wrong. For the subject, being and the active realization of being are one and the same. Openness has to be lived in and through our understanding; it has to become relevant and productive in the way we make experiences and encounter, or better: embrace disappointment.

A model we could use to make this clear can be found in Aristotle's conception of virtue. Humans, he famously states, do not possess virtue by nature but acquire it through habit, ethos. This means that "states of character arise out of like activities," so that one becomes just by performing the required acts "in our transactions with other men," and courageous "by doing the acts that we do in the presence of danger, and being habituated to feel ... confidence. ${ }^{.7}$ In an analogous sense we can say that individuals need to train and cultivate their openness in order for it to thrive and to become a habit, that is, a part of their being. Like the virtuous individual for Aristotle has to get used to facing the negativity of danger or human transgressions in order to acquire courage or justice, the individual who engages in understanding has to face the negativity of experience in order to achieve a habit of openness toward others or traditions. Openness is no natural disposition that can only be used in one specific way but a modifiable being that becomes more stable or more unreliable according to the way in which it is used. Negativity could so be used as an experience in which the subject not only encounters herself explicitly but strives consciously toward achieving a new habitual stance toward others or the world.

In this sense, hermeneutics would have practical relevance in the promotion of a culture of receptivity and openness. It would be a culture of negativity, to be

6Cf. TM 360/372, with respect to questioning as an art of its own.

7 Aristotle, Nicomachean Ethics, book II, 1. 
sure, which would not claim to cultivate understanding itself - because understanding in its ultimate fulfillment cannot be mastered or produced - but the way towards it, that is, the acceptance of disappointment without which one cannot truly understand. It would promote and foster the critical restraint of one's own immediate impulses to understand. Gadamer, again, does not say much about such conclusions that can be drawn from his own philosophy (and that do not seem to contradict his position at all). His skepticism toward the modern attempt to master almost everything, including one's own understanding, is too strong to let him elaborate such possibilities further. There is, however, another historical example that could have shown him the way to a more positive conception of subjective experience and the way it can be cultivated: Plato's notion of dialectic and the education that is needed in order to use dialectic appropriately. ${ }^{8}$

\section{Dialectic as Self-Education}

Gadamer's continuous and life-long dialogue with Plato is far too rich to be summarized in a few words. For the purpose of this paper, we will limit ourselves to the themes of negativity and openness that are present in this dialogue as well. Both themes intersect in the conception of dialectic. From the start, Gadamer emphasizes the fact that dialectic has to be seen as a form of

8 The idea of culture, which could easily be linked to this discussion, has a negative connotation in Gadamer's work. He almost never mentions it, and where he does so he links it to the metaphysical conception of the subject. Culture, for him, is the product of purely subjective faculties. Truth and Method distinguishes Kultur from Bildung and states, with regard to Wilhelm von Humboldt: "Bildung here no longer means 'culture' - i.e., developing one's capacities or talents." (TM 10/16) While cultivation means to develop "something that is given", in a way that "is a mere means to an end" (TM 10/17), Bildung, understood as "rising to the universal" (TM 11/18), transcends not only the confines of purely subjective capacities, but also leaves all utilitarian considerations behind. In his philosophy of art, culture only appears negatively, i.e., in his reference to the "cultural industry" (Gadamer 1986b, 129) that obfuscates or even degrades the nature of art understood as "play, symbol, and festival." (cf. Gadamer 1986a) In a more positive, although rare use of the word, in an article published shortly after the Second World War, Gadamer refers to Georg Simmel's notion of a "tragedy of culture" to show how humans are torn between pride and desperation; pride because of their achievements, and desperation because of the foolhardiness these achievements entail. (Gadamer 1993a, 157) Gadamer's interpretation of the term of culture might seem overly critical, but it certainly hits an essential aspect of the term. Even if it is notoriously difficult to define, in its prevalent philosophical meaning it always referred to an active, self-empowered capacity. Culture is what we cultivate, what we build up. It can be defined, if ever a definition is possible here, as an amalgam of the Kantian idea of human capacities (Vermögen) and the Nietzschean idea of creative force. See for example in Kant: "A human being has a duty to himself to cultivate (cultura) his natural powers (powers of spirit, mind, and body), as means to all sorts of possible ends." (Kant 1996, 194) And in Nietzsche: "We [have] to know exactly how great the shaping power [plastische Kraft - MS] of a human being, a people, a culture is; by shaping power I mean that power to develop its own singular character out of itself, [...] to recreate broken forms out of itself alone." (Nietzsche 1995, 89) 
openness that transcends the well-defined realm of philosophical theory. For him, it is primarily a "practical" way of using and achieving knowledge. This means that it cannot be reduced to the status of a mere tec nique of definition and argumentation, that is, to the status of a tool employed for theoretical purposes, but has to be applied to the sphere of individual life, both in the dialogue with others and in questions concerning the personal conduct of life. "Practical knowledge," which is Gadamer's term for this specific form of knowledge, originates from the individual in her very own being. All general concepts that are used acquire meaning only in and through the individual to which they apply. (Gadamer 1985, 234) ${ }^{9}$ The dialectical method, hence, has as its primary goal the purpose to "destroy" the reassurance we seek in our usual opinions; it is a "vigilance of the soul" that keeps it eager to look out for what is truly useful for itself. (GADAMER, 1985, 238) ${ }^{10}$

For this interpretation of dialectic, the Socratic life of self-examination obviously gives the model. Dialectic is neither a rigid or formalized method, nor a tool to remain victorious in debates, but the expression of an essentially ethical commitment to the good life. Gadamer refers repeatedly to the unity of logos and ergon in the figure of Socrates, that is, to the unity of theoretical claims about the nature of the good and the actions and habits through which such claims are validated and realized. (Gadamer 1986, 99-100, Gadamer 1980, 3) For Gadamer, even in Plato's late dialogues, where the ethical dimension of dialectic is not so obvious anymore, it is far from becoming a form of pure theory, disconnected from individual life:

The interweaving of the highest genera in the Sophist and, even more, the dialectical exercise which the young Socrates is put through by the elder Parmenides lead only to negative insight that it is not possible to define an isolated idea purely by itself, and that the very interweaving of the ideas militates against the positive conception of a precise and unequivocal pyramid of ideas. (GADAMER 1980, 110)

Dialectic shows that in each determination of an object a combination of ideas is necessary, without pointing at their ultimate unity or foundation. There

9For a later account of the idea of "practical knowledge," see Gadamer 1986, 37.

10 For the motive of vigilance, see Risser 1997, 169-171. 
is no "clear, unambiguous structure of Being" that dialectic would represent in a way that could bring the quest for knowledge to an end. (Gadamer 1980, 110) This also concerns the ultimate goal both of knowledge and individual life, the idea of good. Here again, the Socratic "challenge" is the model which forces us to be "aware of what we do not know in our having to know the good." only Socrates who incorporates this awareness: "It is characteristic and significant that Plato himself consistently delimits knowledge of the good from all other knowledge only in a negative way." (Gadamer 1986, 34) ${ }^{12}$ Whenever dialectic is used in a purely theoretical sense, it appears as theory that limits all theoretical claims. It is then a "negative dialectic," Gadamer states, albeit with some hesitation (the term 'negative' is put in quotation marks, see Gadamer 1991a, 108).

And yet, in order to be able to realize such a "negative dialectic," a degree of mastery is necessary that does not come naturally to the philosophizing mind. Of course, it makes sense to emphasize the negative function of dialectic, which helps Plato to criticize the sophistic presumption of being an expert in everything. But if we take the Seventh Letter which for Gadamer is a crucial testimony, ${ }_{13}^{13}$ we see that the task of dialectic is not only about the renunciation of knowledge, or about the awareness of not knowing what the good is. True insight comes after long studies, as Plato says, and long and repeated dialogues about "untruth and truth of being as a whole." (Epist. VII, 344 b) It requires the student to become familiar with a multitude, if not the totality of possible objects. Plus, it needs extensive methodological exercise in the study of all relevant forms of epistemic pursuit, such as names, definitions, images, and intellectual knowledge. (Epist. VII, $342 \mathrm{~b}$ ) And finally, it requires the student to be exposed to the benevolent and ungrudging scrutiny of other students, in order to validate the insights she achieves. (Epist. VII, 344 b) In all these aspects, dialectic bears for Plato a theoretical complexity that Gadamer seems to underplay in his almost exclusive focus on the individual, if not existential, use of knowledge.

This leads us back to the paradoxical structure of openness. On the one hand, the dialectic described in the Seventh Letter is pure transcendence towards truth. The individual ultimately yields to the self-presence of the idea. Gadamer is right in stressing this point. But on the other hand, it requires purpose and critical knowledge to be prepared for this revelation. That is, it needs a highly sophisticated conceptual training in order to know what such revelation even

$11, \ldots$...sich des Nichtwissens im Wissenmüssen des Guten bewußt zu sein.“ (Gadamer 1991, 108) 12 For an interpretation of the late Plato, see also 1991b, 208-209.

13 See his important article on Dialectic and Sophism in Plato's Seventh Letter, in Gadamer 1991b, 93-123. 
means, not to mention a high degree of self-control in order to deal responsibly with it. Such training cannot be achieved without an individuals' commitment to truth and a process in which she educates herself in her capacity to know. Dialectic is intrinsically linked to a form of education, of paideia; it is a highly reflective way of learning that forces the individual both to examine and restrain habitually her intuitions and opinions.

Gadamer is clearly aware of this because even for him dialectic could not yield any valid insight if it did not teach the individual a way of dealing successfully with theoretical concepts and principles. ${ }^{14}$ Dialectic helps to develop a persistent attitude and bearing, a hexis, in the individual, he states. (Gadamer 1985,242 ) It also helps to acquire the "art of questioning," which is a necessary step not only in the interpretation of a text, but also, and more fundamentally, in maintaining the individual's "orientation toward the open." (TM 360/372) ${ }^{15} \mathrm{Fi}$ nally, it helps the individual "holding steadfast in the face of all confusion ..., especially in regard to the idea of good." (Gadamer 1986, 100) Dialectic, hence, is a form of mastery that allows the individual to overcome the confusions and solve the false aporias the sophists produce in order to have their way. It is an "art" one has to practice to become ever "more dialectical," that is, ever more aware of the true meaning of things. (cf. GADAMER, 1991b, 122).

Obviously it would be impossible to deduce an individual's orientation toward the good by means of mere conceptual differentiations, as it would be impossible to create the unity of logos and ergon by means of logos only. But still, if the individual wants to be able to know with certainty both what she knows and what she does not know, she has to achieve the capacity to refute and deny all misleading or presumptuous claims. She has to embark on the way of a "negative dialectic" that targets all assumptions, including the assumptions concerning the good. Otherwise, the ergon that is achieved in the good life would be a random result.

In his account of Plato's dialogues, Gadamer shows an example of how the subject can become aware of herself and at the same time educate herself to achieve a persistent and transparent attitude toward the good life. Dialectic, he states at least implicitly, is a way in which the subject can become more conscious of her conduct of life and initiate a transformation of the basic habits she has achieved. The subject thus achieves a more explicit role than she is ever granted in Truth and Method, where the humanistic conception of understanding remains tied to the assumption of being, understood as opposite of an

14For dialectic as an art of differentiation, cf. Gadamer 1986, 98.

15 Translation modified. 
intentional act. Individual being in Truth and Method is seen as an energeia and "realization" (Vollzug) that remains inaccessible to all subjective control. (cf. TM 112/118, TM 250/264) Only in relation to Plato, it seems, Gadamer acknowledges the critical potential that can lie in understanding if all faculties of the subject that are involved are also brought to the fore.

Hermeneutics, we can learn from him, means to go the way of disappointment. Our fundamental openness toward the world has to be based on the negative experience that lies in realizing how much it takes not to understand too easily, both ourselves and the others' voice. Integrating the openness to disappointment into the shape of one's identity is the way in which hermeneutics can teach us to see our role as subjects.

\section{Referência Bibliográfica}

Hans-Georg Gadamer. Truth and Method (= TM), transl. J. Weinsheimer and D.G. Marshall, second revised edition (New York: Continuum, 2003). German edition: Wahrheit und Methode. Grundzüge einer philosophischen Hermeneutik, in: Gesammelte Werke 1: Hermeneutik I, sixth edition (Tübingen: J.C.B. Mohr (Paul Siebeck), 1990). [In most of the quotes, the first page number refers to the English edition, the second one to the German original.]

."Subjektivität und Intersubjektivität, Subjekt und Person"(1975), Gesammelte Werke 10. Hermeneutik im Rückblick (Tübingen: J.C.B. Mohr (Paul Siebeck), 1995): 87-99.

. „Prometheus und die Tragödie der Kultur“ (1946), Gesammelte Werke 9. Ästhetik und Poetik II (Tübingen: J.C.B. Mohr (Paul Siebeck), 1993): 150161. [1993a].

„Zwischen Phänomenologie und Dialektik. Versuch einer Selbstkritik“ (1985), in: Wahrheit und Methode. Ergänzungen, Register. Gesammelte 18 Werke 2: Hermeneutik II, second edition (Tübingen: J.C.B. Mohr (Paul Siebeck), 1993): 3-24. [1993b].
GADAMER, Hans-Georg. „Sokrates’ Frömmigkeit des Nichtwissens" (1986), Gesammelte Werke 7. Griechische Philosophie 3: Plato im Dialog (Tübingen: J.C.B. Mohr (Paul Siebeck), 1991): 83-117. [1991a].

.Plato's Dialectical Ethics. Phenomenological Interpretations Relating to the 'Philebus', translated and with an introduction by R.M. Wallace (New Haven: Yale University Press, 1991). [1991b].

. "Text and Interpretation", Dialogue and Deconstruction: The Gadamer-Derrida-Encounter, ed. D. Michelfelder and R. Palmer (Albany: SUNY Press, 1989): 21-51.

"The Relevance of the Beautiful", The Relevance of the Beautiful and Other Essays, ed. Robert Bernasconi (Cambridge: Cambridge University Press, 1986): 1-56. [1986a]

. "The Play of Art", The Relevance of the Beautiful and OtherEssays, ed. Robert Bernasconi (Cambridge: Cambridge University Press, 1986): 123-130. 
BERKELEY, George, Principles of Human Knowledge, in Oeuvres Choisies, traduction, préface et notes de André Leroy, Paris, Aubier-Montaigne, 1960, Tome I.

FRAGA, Gustavo de, "De Husserl a Heidegger. Elementos para uma problemática da fenomenologia", in Biblos, vol. XL, 1954, pp. 1-260.

FREUD, Sigmund, Das Ego und das Id, trad. franc. de S. Jankélévitch, "Le Moi et le Soi », in Essais de Psychanalyse, Paris, Payot, 1948.

HUME, David, A Treatise of Human Nature, trad. port., Tratado da Natureza Humana, Lisboa, Fundação Calouste Gulbenkian, 2001.

HUSSERL, Edmund, Cartesianische Meditationen, in Husserliana, Band I, Den Haag, Martinus Nijhoff, 1950a.

Die Idee der Phänomenologie, in Husserliana, Band I, Den Haag, Martinus Nijhoff, 1950 b.

Ideen zu einer reinen Phänomenologie und phänomenologische Philosophie. Erstes Buch, in Husserliana, Band III, Den Haag, Martinus Nijhoff, 1950c.

. The Idea of the Good in Platonic-Aristotelian

Philosophy, translated and with an introduction and annotation by P. Ch. Smith (New Haven: Yale University Press, 1986).

Praktisches Wissen“ (1930), Gesammelte Werke 5: Griechische Philosophie 1 (Tübingen: J.C.B. Mohr (Paul Siebeck), 1985): 230-249.

. "Logos and Ergon in Plato's Lysis" and "Dialectic and Sophism in Plato's Seventh Letter", Dialogue and Dialectic. Eight Hermeneutical Studies on Plato, translated and with an introduction by $\mathrm{P}$. Ch. Smith (New Haven: Yale University Press, 1980): 1-20 and 93-123.
GRONDIN, Jean. “Gadamer's Basic Understanding of Understanding", The Cambridge Companion to Gadamer, ed. R.J. Dostal (Cambridge: Cambridge University Press, 2002): 36-51.

KANT, Immanuel. The Metaphysics of Morals, translated and edited by Mary Gregor (Cambridge: Cambridge University Press, 1996).

NIETZSCHE, Friedrich. Unfashionable Observations, translated by Richard T. Gray. The Complete Works of Friedrich Nietzsche, vol. II (Stanford: Stanford University Press, 1995).

RISSER, James. Hermeneutics and the Voice of the Other: Re-reading Gadamer's Philosophical Hermeneutics (Albany: SUNY Press, 1997). 